\title{
APPLICATION OF ANN TO THE SORPTION EQUILIBRIUM MODELLING OF HEAVY METAL IONS ON CLINOPTILOLITE
}

\author{
ZASTOSOWANIE SSN W MODELOWANIU RÓWNOWAGI SORPCYJNEJ \\ JONÓW METALI CIĘŻKICH NA KLINOPTYLOLICIE
}

\begin{abstract}
The latest achievements in the field of mathematical modelling include the application of artificial neural networks (ANN). A growing interest in the ANN is confirmed by the number of publications devoted to the applicability of ANN in chemical, process and environmental engineering. A recent dynamic development of ANN provided an efficient and universal tool that is used to solve many tasks, including modelling, approximation and identification of objects. The initial step of applying the network to a given process consists in the determination of weights of the proposed neural network structure. This is performed on the basis of training data. A network that is properly trained allows correct information to be obtained on the basis of other data which have not been used in the network training. In most cases the network training is performed on the basis of a known mathematical model. However, the training of a network can be also performed using experimental data. In this paper, the sorption isotherms were predicted by means of a multilayer perceptron (MLP). Calculations were made using a training program written in Matlab, which took advantage of the Lavenberg-Marquardt procedure. In the last decade a growing interest is observed in inexpensive and very cheap adsorbents to remove heavy metal ions. Clinoptilolite is the mineral sorbent extracted in Poland used to remove heavy metal ions from diluted solutions. Equilibrium experiments were carried out to estimate sorptivity of a clinoptilolite and its selectivity towards $\mathrm{Cu}$ (II), $\mathrm{Zn}$ (II) and $\mathrm{Ni}$ (II) ions for multicomponent solution. Calculations with the use of MLP enabled description of sorption isotherms for one, two and three ions which were present at the same time in the solution. The network also enabled an analysis of sorption of the single ion, taking into account the effect of its concentration.
\end{abstract}

Keywords: artificial neural network, adsorption equilibrium, heavy metals ions, clinoptilolite

\section{Introduction}

The water purification concerns of removal of many chemical compounds. Heavy metal ions with a particularly negative impact on living organisms are considered. It is recommended to remove them by means of adsorption from diluted solutions. However it is not easy to realize this problem. In order to remove pollutants from the liquid solution by adsorption process it is necessary to use solid adsorbents with a highly developed surface. The most popular, recorded in the literature adsorbents are zeolites, silica gel, activated

\footnotetext{
${ }^{1}$ Faculty of Process and Environmental Engineering, Lodz University of Technology, ul. Wólczańska 213, 90-924 Łódź, Poland, phone +48 426313788

*Corresponding author: tomczak@wipos.p.lodz.pl
} 
carbons etc. Zeolites have excellent adsorption properties and differ strongly from the other adsorbents. Clinoptilolites may occur in sedimentary rocks, volcanic and metamorphic depositions. In Poland, the mineral layers are found mainly in sedimentary rocks in the vicinity of Rzeszow. The content of pure clinoptilolite in mudstone is $4 \div 30 \%$ only. Zeolites were used to remove impurities and heavy metal ions from aqueous solutions previously [1]. Studies on the use of clinoptilolite have drawn constantly attention [2,3] and it is often considered by the Polish scientists [4]. It was observed that the removal of ions on the zeolites occurs as a result of simultaneous processes, adsorption and ion exchange. Particularly selectivity against heavy metals proved to be in the form of sodium clinoptilolite.

\section{The study of the sorption equilibrium}

In experiments a sorbent on the basis of the natural zeolite (Invest Holding Poland „ZEOKlin”) was prepared. The main component of the sorbent is clinoptilolite. In the study material of grain size $1 \div 3 \mathrm{~mm}$ and density of $2160 \mathrm{~kg} / \mathrm{m}^{3}$ was used. Clinoptilolite was washed with distilled water to remove the physical impurities and then dried at $105^{\circ} \mathrm{C}$ to remove zeolite water. The modification consisted of soaking for 24 hours in $3 \% \mathrm{NaCl}$ solution, washing with distilled water to the disappearance of chloride ions and dried at $105^{\circ} \mathrm{C}$. This chemical treatment was to increase the capacity of clinoptilolite ion exchange that causes the displacement of all the mobile cation present in the crystal lattice. Sorbent obtained in this way took a form of sodium clinoptilolite, which is particularly selective against heavy metal ions. Selected results of equilibrium and kinetics sorption were presented in the work [5]. The reagents used for chemical modification and preparation of the solutions came from the „Chempur" (Poland). Adsorbate was obtained using demineralized water, and salts: $\mathrm{CuSO}_{4} \cdot 5 \mathrm{H}_{2} \mathrm{O}, \mathrm{NiSO}_{4} \cdot 6 \mathrm{H}_{2} \mathrm{O}, \mathrm{ZnSO}_{4} \cdot 7 \mathrm{H}_{2} \mathrm{O}$.

The study of adsorption equilibrium was carried out at $30^{\circ} \mathrm{C}$, and $\mathrm{pH}=5 \div 6$. The appropriate mass of sorbent was placed in conical flasks and mixed with salts solution (the range of concentrations $10 \div 200 \mathrm{mg} / \mathrm{dm}^{3}$, total solution volume $200 \mathrm{~cm}^{3}$ ). The samples were inserted into a thermostated shaker and kept to equilibrium state. Examinations of samples were carried out on ion chromatograph Dionex ICS-1000.

Knowing the initial $\mathrm{c}_{0}$ and equilibrium value $c^{*}$ in the solution sorption capacity $q^{*}$ was calculated from the relation:

$$
q^{*}=\frac{V}{m} \cdot\left(c_{0}-c^{*}\right)
$$

where: $c_{0}$ and $c^{*}$ - initial and equilibrium concentration of heavy metal ions $\left[\mathrm{mg} / \mathrm{dm}^{3}\right]$, $q^{*}$ - equilibrium concentration in adsorbent $[\mathrm{mg} / \mathrm{g}], V$ - solution volume $\left[\mathrm{dm}^{3}\right], m$ - mass of adsorbent [g].

For single ion adsorption equilibrium can be described using classical equations such as Freundlich, Langmuir and Dubinin-Radushkevich etc. However, a better approximation for single ion in ternary mixture (Fig. 1) was obtained using the exponential equation of the form [6]:

$$
q^{*}=A_{1} \exp \left(\frac{c^{*}}{t}\right)+y_{0}
$$

where: $A_{1}, t, y_{0}$ - constants. 


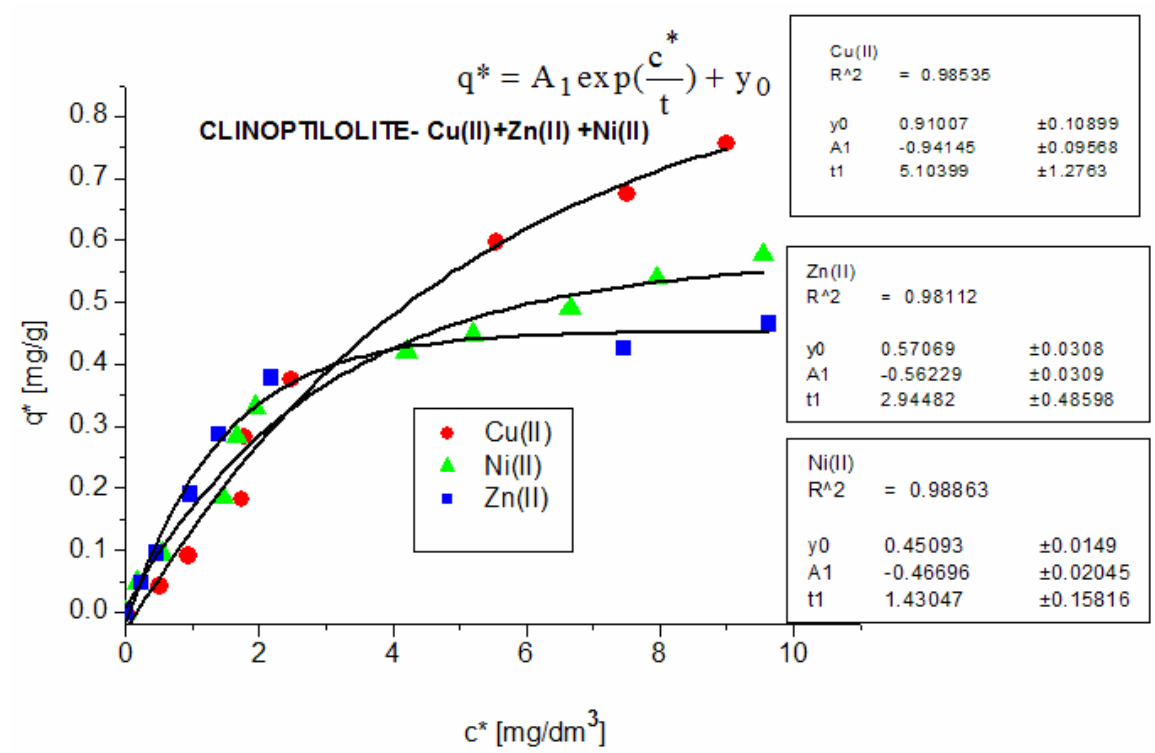

Fig. 1. Equilibrium curves of clinoptilolite - heavy metal ion in ternary mixture

Considering multicomponent systems, increasing number of components and structural complexity of the chemical-adsorbent it is expected complex interaction among sorbent and metal ions. Sorption of metal ions in such systems is the problematic issue. In the literature there are several approaches to this subject for natural and synthetic sorbents: clinoptilolite [7]; montmorillonite [8, 9]; mordenite [10]; synthetic resin [11, 12] but the results of mathematical modelling are not satisfactory. For that possibility of using artificial neural networks to describe the sorption equilibrium in multicomponent systems is proposed in this paper.

\section{Description of the artificial neural network}

The development of the theory of artificial neural networks (ANN) and the possibility of their practical realization in recent years have created a new, effective and versatile tool with which solved a series of tasks and problems in many fields. Extensive use of ANN result of the following characteristics:

- the possibility of approximation of any nonlinear mapping,

- parallelism of information processing,

- the ability to learn and adapt,

- processing of signals from multiple inputs and generating multiple outputs (multidimensional systems).

By artificial neural network structure should be understood that imitates a biological neural network activity. It creates a set of mutually connected basic elements (artificial neurons) that process the input signal.

Currently, there are many known types of networks performing different tasks. According to the feed signals direction the following ANN types can be distinguished: feed 
forward network eg single layer perceptron, multilayer perceptron, Kohenen network, radial basis function network, fuzzy logic network; recurrent network eg Hopfield, Elman, Jordan networks.

Particularly popular is the use of feed forward network in a layered system. The signals are fed from the input layer, pass into hidden layers and go out from network. Most often exist all possible connections between neurons. Those networks are named multilayer perceptron (MLP) [13]. Scheme of a multilayer network is shown in Figure 2. The scheme is commonly used in practice. Usually for input and output layer take the form of linear transfer functions. While for hidden neurons is selected non-linear transfer function eg sigmoidal. Transfer function that describes the input-output of the MLP has the form:

$$
\mathrm{y}=F(\mathrm{x})=f\left(\sum_{j} w_{o j} f\left(\sum_{k} w_{j k} f\left(\cdots f\left(\sum_{m} w_{n m} x_{m}\right) \cdots\right)\right)\right.
$$

where: $f(\cdot)$ - transfer function of neuron (eg sigmoidal), $w$ - weight.

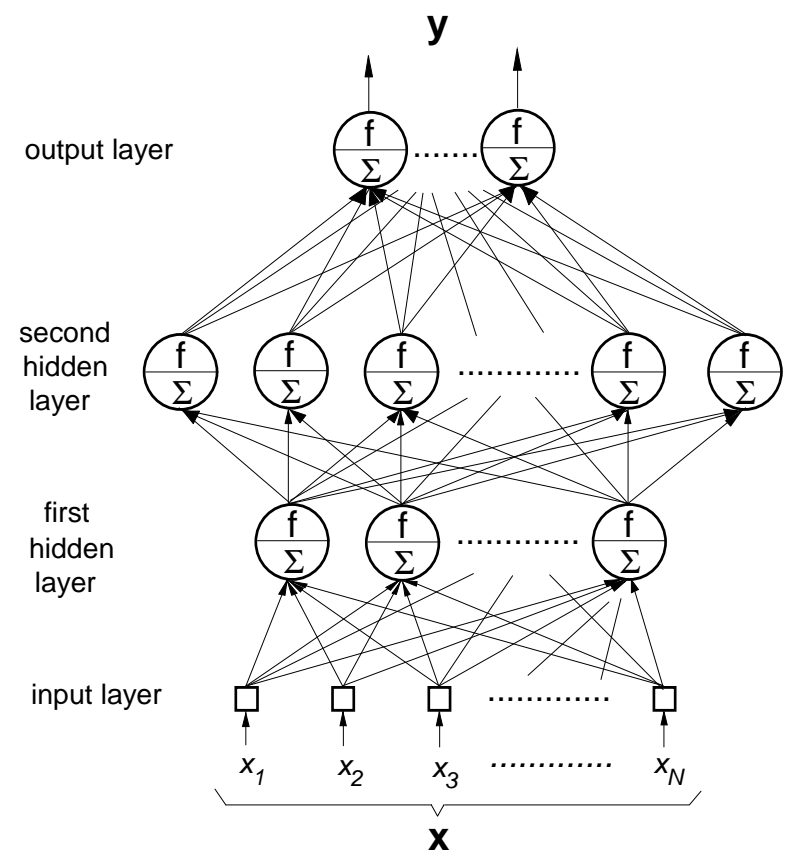

Fig. 2. Architecture of MLP-type network

The computing techniques enabled introduction of more complicated mathematical models, which can accurately simulate real object. However, these techniques require good acquaintance of a key parameter of process - interrelations and interactions, which decide about general realization of process. In case of ANN it is not necessary to know all complicated structure of the object a priori. However, to rely on a neural model it should not be regarded as a "black box" model. Efforts should be made, when constructing the 
network topology, to reflect the mechanism of the process. Generally, in order to describe the action of the ANN at least three basic properties should be known: neuron model (knowledge of the transfer function), the network topology (connections between neurons) and the method of learning [14-16].

Learning of a network is based on experimental data. Usually available experimental data set is divided into two parts: training and testing. Learning of network is a process in which the variable parameters are matched by an external force. Tactics of learning (learning algorithm) is determined by the manner in which the network parameter changes take place.

Typically, the learning process relates to matching network connections weights. Although, in some cases, the learning process is also accompanied by tuning some other network parameters such as the matching scaling factor, the number of hidden layers, or the choice of transition functions, etc.

\section{Application of ANN to describe the sorption equilibrium}

The purpose of using ANN modelling is to search for the network structure and corresponding weights to reduce to the minimum number of weights and obtain satisfactory results in terms of approximation of experimental data, statistical tests are usually applied. Calculated and experimental data generated from the network were compared.

In each case an assessment was conducted based on the squared coefficient of determination $\left(R^{2}\right)$ and mean square error $\left(\delta_{m}\right)$ according to the equations presented below:

- squared of determination coefficient

$$
R^{2}=1-\frac{\sum_{i=1}^{p}\left(y_{i \exp }-y_{i c a l}\right)^{2}}{\sum_{i=1}^{p}\left(y_{i \exp }-y_{m}\right)^{2}}
$$

where:

$$
y_{m}=\frac{\sum_{i=1}^{p} y_{i \exp }}{p}
$$

- mean square error

$$
\delta_{m}=\sqrt{\frac{\sum_{i=1}^{p}\left(y_{i \exp }-y_{i c a l}\right)^{2}}{p}}
$$

where: $p$ - number of measurements, $y_{\text {iexp }}$ - experimental value, $y_{i c a l}$ - calculated value, $y_{m}$ - averaged value of the experimental data.

As mentioned above sorption of metal ions in multicomponent systems is one of high complexity issues. There may be two, three or more ions in solution. Modelling the equilibrium of such a system is more complicated and should take into account the 
interaction between the ions and their mutual influence on the sorption efficiency. This kind of knowledge is not necessary when using ANN. It was found that sorption isotherms for a single ion, and mixtures of ions in various configurations can be described by means of artificial neural networks [17]. In this case a MLP network used is shown in Figure 3. The Levenberg-Marquard learning method in this calculation was applied.

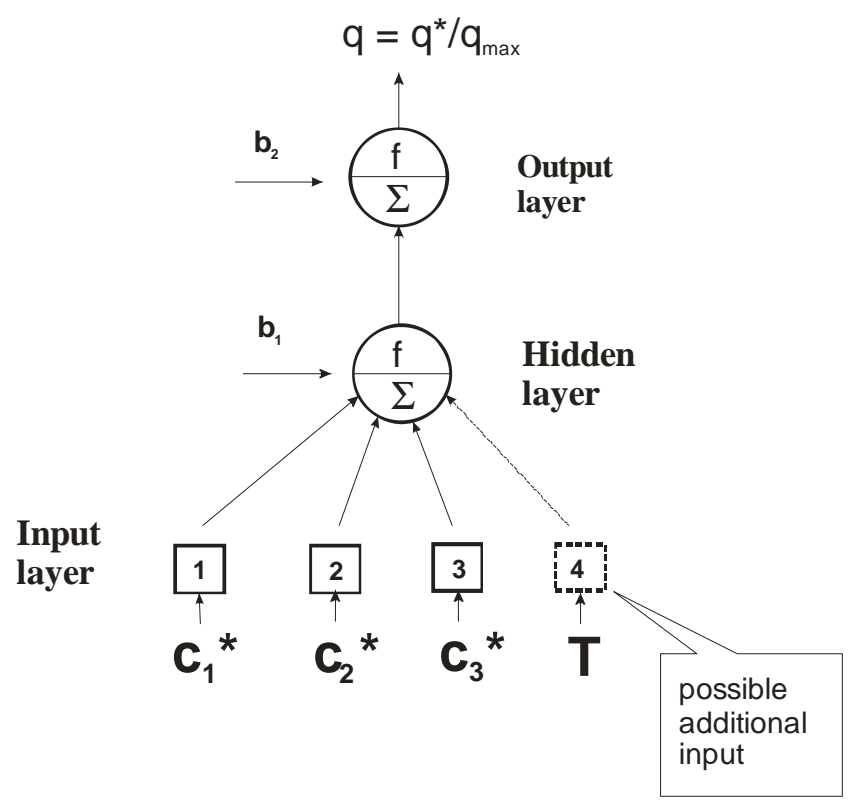

Fig. 3. Architecture of proposed MLP network

Data to the network training were taken from experiments for the single and multicomponent systems at $T=$ const. If the water solution consists of a single component eg $\left(c_{1}^{*} \neq 0\right)$ then the concentration of the two other components at the input to the network is kept at zero $\left(c_{2}^{*}=0, c_{3}^{*}=0\right)$. Depending on the number of components in the mixture (one, two or three components) 7 different combinations are possible.

After training the network the results of sorption of mono-, di- and / or ternary mixtures at $T=$ const can be obtained

$$
q=q^{*} / q_{\max }=f_{M L P}\left(c_{1}^{*}, c_{2}^{*}, c_{3}^{*}\right)
$$

The same calculation should be carried out in the next cycle calculation for the other sorption temperature based on the presented network architecture.

It is also possible to expand the network of the fourth input to the network to use temperature. In this case the results may be subject to additional error.

Similar considerations were carried out for the system clinoptilolite - metal ions. Calculations were performed based on the equilibrium sorption data obtained at $30^{\circ} \mathrm{C}$. After a preliminary analysis of network topologies (adjusted number of hidden neurons, the determination of logistic transfer function) the following network is obtained as shown in Figure 4. 


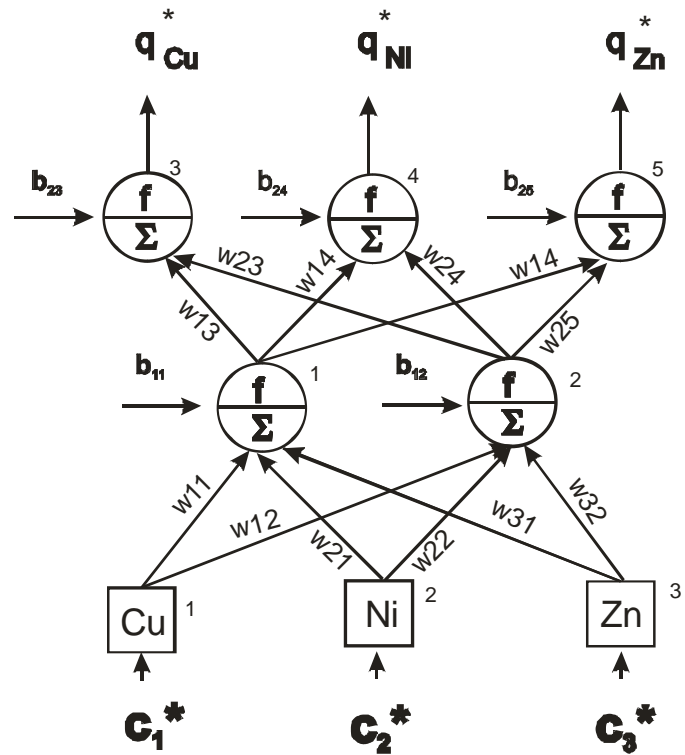

Fig. 4. MLP network for sorption equilibrium calculation for the system: clinoptilolite $-\mathrm{Cu}(\mathrm{II})+\mathrm{Ni}(\mathrm{II})+\mathrm{Zn}(\mathrm{II})$

The values of weights and biases of MLP network were presented below: weight ( $w 11$, $w 12, \ldots, w 25)$ and biases $(b 11, \ldots, b 25)$. This function is illustrated by equation (8) for copper ion. For the rest ions the form is analogous, changing the weights and biases according to the connections between elements in the structure of the network.

$$
\begin{gathered}
q_{C u}=q^{*} / q_{\max }=f\left[w_{13} f\left(c_{1} w_{11}+c_{2} w_{21}+c_{3} w_{31}+b_{11}\right)+\right. \\
\left.+w_{23} f\left(c_{1} w_{12}+c_{2} w_{22}+c_{3} w_{32}+b_{12}\right)+b_{23}\right] \\
\text { weight: input - hidden neurons } \\
-2.7787946 \mathrm{e}+0001.1644560 \mathrm{e}+001-3.8136596 \mathrm{e}+000 \\
-1.0925376 \mathrm{e}+0001.4706303 \mathrm{e}+000-1.8842289 \mathrm{e}+000
\end{gathered}
$$

\section{biases: hidden neurons}

$$
\begin{aligned}
& -1.1180272 \mathrm{e}+001 \\
& -1.1817181 \mathrm{e}+000
\end{aligned}
$$

weight: hidden neurons - output

$2.0908393 \mathrm{e}+000-2.1893049 \mathrm{e}+001$

$3.1107976 \mathrm{e}+000-2.1494892 \mathrm{e}+001$

$6.5219104 \mathrm{e}-001-2.5058288 \mathrm{e}+001$

biases: output layer

$-2.1373308 \mathrm{e}-001$

4.8195832e-001

$7.9874906 \mathrm{e}-001$ 
As a result of calculations using the ANN values of the sorption equilibrium depending on the solution composition and concentration were obtained. Comparison of experimental and calculated value is shown in Figure 5. In the case of neural modelling is possible to calculate all $\mathrm{q}^{*}$ not only for the experimental points but in the whole range of consideration. There is therefore a possibility of complete the data, rejection some due to measurement error or to extrapolate beyond the range. Figure 6 shows the correlation between the experimental and calculated data for the three component solution of heavy metal ions.

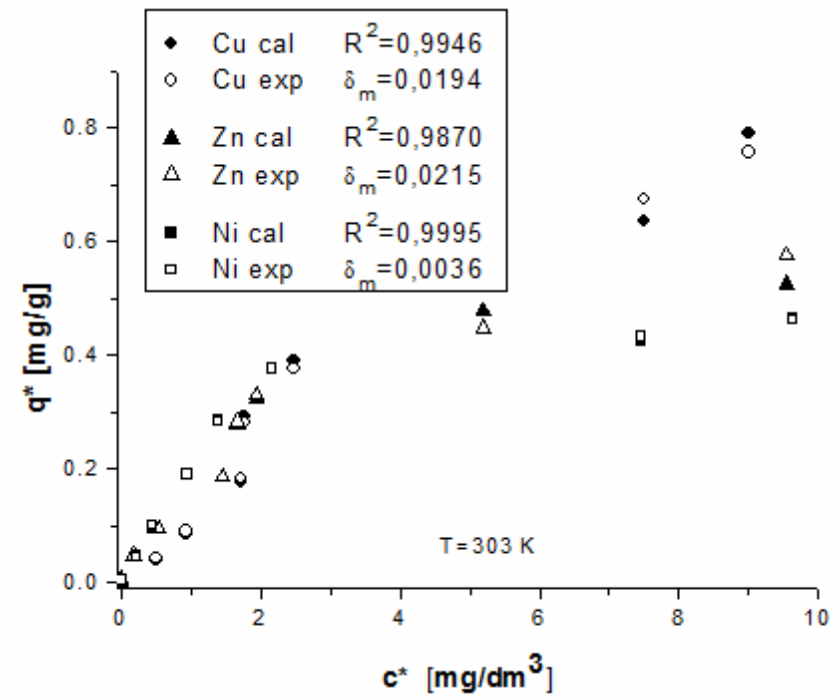

Fig. 5. MLP calculated sorption isotherms for the clinoptilolite $-\mathrm{Cu}$ (II) $+\mathrm{Ni}$ (II) $+\mathrm{Zn}$ (II) system

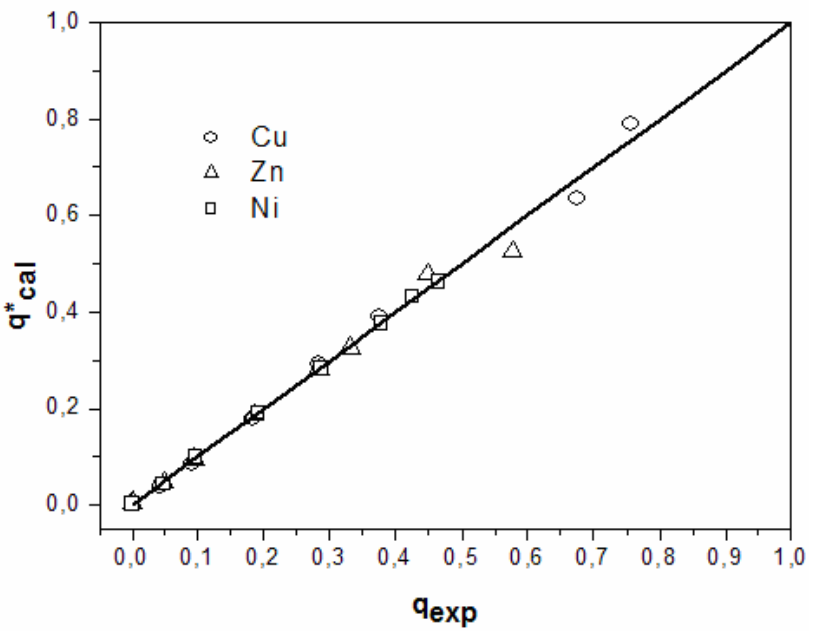

Fig. 6. Correlation of calculated and experimental $\mathrm{q}^{*}$ for the clinoptilolite $-\mathrm{Cu}(\mathrm{II})+\mathrm{Ni}(\mathrm{II})+\mathrm{Zn}$ (II) system 
Neural computing presented in this paper pointed out another possibility to obtain calculated data of the sorption equilibrium. Typical approach to describe experimental data is to use one of the known equations. Sometimes the data fitted to the equation of chosen sorption isotherm is unsatisfactory, then the data can be described by applying the ANN, which after properly developed architecture and training, give a very good fit.

The neural method of calculations was also confirmed for the foamed chitosan $\mathrm{Zn}(\mathrm{II})+\mathrm{Cu}(\mathrm{II})+\mathrm{Cr}(\mathrm{VI})$ system. The $\mathrm{Cr}(\mathrm{VI})$ exists in the solution in the form of anions $\mathrm{Cr}_{2} \mathrm{O}_{7}^{2-}, \mathrm{HCr}_{2} \mathrm{O}_{7}^{-}, \mathrm{HCr}_{2} \mathrm{O}_{4}^{-}$or $\mathrm{Cr}_{2} \mathrm{O}_{4}^{2-}$. Calculations of multicomponent equilibrium sorption in this case are difficult, not only because of the form of chromium ions but also chitosan.

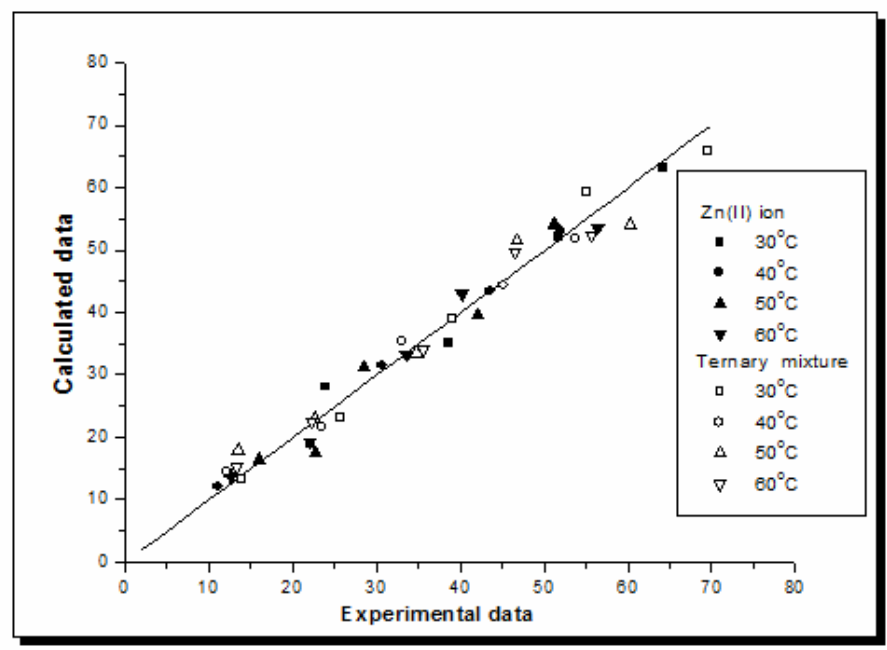

Fig. 7. Comparison of experimental and calculated data for the adsorption of $\mathrm{Zn}$ (II) in ternary mixture

Graphical correlation of experimental and calculated results for $\mathrm{Zn}$ (II) in ternary mixture using the ANN are illustrated in Figure 7.

\section{Conclusions}

The study demonstrated the usefulness of the natural zeolite clinoptilolite to adsorb heavy metal ions from diluted aqueous solutions. It was confirmed that the selectivity of this sorbent was in the following order: $\mathrm{Cu}(\mathrm{II})>\mathrm{Zn}(\mathrm{II})>\mathrm{Ni}(\mathrm{II})$.

Determination of sorption equilibrium is the starting point for further research and calculations related to the kinetics and dynamics of adsorption. Usually the sorption equilibrium is described by one of the classical equations such as Langmuir and Freundlich etc. In the case of complex, multicomponent systems and novel sorbents of natural origin such description may be ambiguous. This is also the case when the adsorption mechanism can be mixed, eg physical, chemical, and ion exchange.

In such a case it is possible a different approach. The application of artificial neural networks to mathematical modelling of sorption isotherms was presented and discussed in the paper. In the case of ANN is not necessary to know the mathematical description of 
sorption equilibrium. After selecting the best network architecture and its training and testing on sets of data we can proceed to prediction. The quality of the calculations is also subjected to statistical evaluation. As demonstrated highly satisfactory results were achieved. On this basis it can be concluded that ANN is a useful mathematical tool to calculate sorption isotherms for multicomponent systems. It is also possible to calculate isotherms at different temperatures.

\section{References}

[1] Gomonaj VI, Golub NP, Szekeresh KY, Leboda R, Skubiszewska-Zięba J. Badania nad przydatnością zakarpackiego klinoptylolitu do sorpcji jonów $\mathrm{Hg}(\mathrm{II}), \mathrm{Cr}(\mathrm{III}) \mathrm{i} \mathrm{Ni}(\mathrm{II})$ z roztworów wodnych. Ochr Środ. 1998;4(71):3-6.

[2] Erdem E, Karapinar N. Donat R. The removal of heavy metal cations by natural zeolites. J Colloid Interf Sci. 2004;280:309-314. DOI: 10.1016/j.jcis.2004.08.028.

[3] Sprynskyy M, Lebedynets M, Zbytniewski R, Namieśnik J, Buszewski B. Ammonium removal from aqueos solution by natura zeolite. Transcarpathian modernite: kinetics, equilibrium and column test. Sep Purif Technol. 2005;46:155-160. DOI: 10.1016/j.seppur.2005.05.004.

[4] Kosobucki P, Kruk M, Buszewski B. Immobilization of selected heavy metals in sewage sludge by natural zeolites. Bioresource Technol. 2008;99:5972-5976. DOI: 10.1016/j.biortech.2007.10.023.

[5] Tomczak E, Sulikowski R. Opis równowagi i kinetyki sorpcji jonów metali ciężkich na klinoptylolicie. Inż Aparat Chem. 2010;1:113-15.

[6] Tomczak E. Sorption equilibrium of heavy metal ions on modified chitosan beads. Ecol Chem Eng A. 2008;15(7):694-702.

[7] Petrus R, Warchoł J. Heavy metal removal by clinoptilolite. An equilibrium study in multi-component system. Water Res. 2005;39:819-830. DOI: 10.1016/j.watres.2004.12.003.

[8] Charlet L, Tournassat $\mathrm{Ch}$. $\mathrm{Fe}$ (II)- $\mathrm{Na}$ (II)-Ca(II) cations exchange on montmorillonite in chloride medium: evidence for preferential clay adsorption of chloride - metal ion pairs in seawater. Aquat Geochem. 2005;11:115-137. DOI: 10.1016/j.compchemeng.2010.05.012.

[9] Krishna BS, Murty DS, Prakash BSJ. Thermodynamics of chromium(VI) anionic species sorption onto surfactant-modified montmorillonite clay. J Colloid Interf Sci. 2000;229:230-236. DOI: 10.1016/jcis.2000.7015.

[10] Tarasevich YI, Krysenko DA, Polyakow VE. Equilibria and heats of ion exchange in the system of mordenite- alkali and alkaline earth cations. Theor Experim Chem. 2006;5(42):320-326. DOI: 10.1007/s11237-006-0060-1.

[11] Pehlivan E, Altun T. The study of various parameters affecting the ion exchange of $\mathrm{Cu}^{2+}, \mathrm{Zn}^{2+}, \mathrm{Ni}^{2+}, \mathrm{Cd}^{2+}$ and $\mathrm{Pb}^{2+}$ from aqueous solution on Dowex 50W synthetic resin. J Hazard Mat. B. 2006;134:149-156. DOI: 10.1016/j.jhazmat.2005.10.052.

[12] Abo-Fara SA, Abdel-Aal AY, Ashour IA, Garamon SE. Removal of some heavy metal cations by synthetic resin purolite C100. J Hazard Mat. 2009;169:190-194. DOI: 10.1016/j.jhazmat.2009.03.86.

[13] Tomczak E, Kaminski W. Drying kinetics simulation by means of artificial neural networks. In: Levy A, Kalman H, editors. Handbook of Powder Technology. Conveying and Handling of Particulate Solids. Amsterdam: Elsevier; 2001;10:569-580. DOI: 10.1016/S0163-3785(01)80059-2.

[14] Haykin S. Neural Networks. A Comprehensive Foundation. New York: Macmillan College Publishing Company; 1994.

[15] Bulsari AB. Neural Networks for Chemical Engineers. Computer-Aided Chemical Engineering, 6, Bulsari AB. editor. Amsterdam: Elsevier; 1995.

[16] Rutkowski L. Metody i techniki sztucznej inteligencji. Inteligencja obliczeniowa. Warszawa: Wyd. Nauk. PWN; 2005 (in Polish).

[17] Tomczak E. Application of ANN and EA for description of metal ions on chitosan foamed structure Equilibrium and dynamics of packed column. Comp Chem Eng. 2011;35:226-235. DOI: 10.1016/j.compchemeng.2010.05.012. 


\title{
ZASTOSOWANIE SSN W MODELOWANIU RÓWNOWAGI SORPCYJNEJ JONÓW METALI CIĘŻKICH NA KLINOPTYLOLICIE
}

\author{
Wydział Inżynierii Procesowej i Ochrony Środowiska, Politechnika Łódzka
}

\begin{abstract}
Abstrakt: W ostatnich dekadach obserwuje się rosnące zainteresowanie zastosowaniem tanich adsorbentów w celu usuwania zanieczyszczeń z roztworów wodnych. Klinoptylolit jest sorbentem mineralnym wydobywanym w Polsce, stosowanym do usuwania jonów metali ciężkich z rozcieńczonych roztworów. Eksperymenty równowagi przeprowadzono w celu oszacowania efektywności sorpcji klinoptylolitu i jego selektywności wobec $\mathrm{Cu}(\mathrm{II}), \mathrm{Zn}$ (II) i Ni(II) w roztworach wieloskładnikowych. SSN umożliwiają obliczenia izoterm sorpcji dla jednego, dwóch lub trzech jonów jednocześnie obecnych w roztworze. W pracy izotermy sorpcji przewidywano za pomocą wielowarstwowego perceptronu (MLP). Obliczenia prowadzono za pomocą własnych algorytmów zgodnie z procedurą Matlaba z zastosowaniem metody uczenia Lavenberga-Marquardta.
\end{abstract}

Słowa kluczowe: sztuczne sieci neuronowe, równowaga adsorpcyjna, jony metali ciężkich, klinoptylolit 